\title{
Anyagi jogi és eljárásjogi változások a civil szervezetek nyilvántartásában (2010-2017)
}

\author{
civil szervezetek - egyesületek - alapítványok - \\ civil szervezetek nyilvántartása
}

Az egyesületekre és alapítványokra vonatkozó anyagi és eljárásjogi szabályozás évtizedek óta teszi próbára a civil szervezetek nyilvántartásba vétele érdekében eljáró képviselők, meghatalmazott ügyvédek és az ebben az ügyszakban eljáró bírósági titkárok és más igazságügyi alkalmazottak türelmét. Ezekkel a problémákkal a korábbi években bírósági titkárként magam is szembesültem, ez inspirálta a szabályozás változásaival, illetve a joggyakorlattal kapcsolatos tapasztalataim összefoglalását.

Az egyesülési jog szabályozása a rendszerváltás idején kivételes újdonságnak számított. A politikai konszenzuskényszerben elfogadott 1989. évi II. törvény elsősorban az alapvető szervezetalakítási normákat foglalta össze. A nyilvántartásba vétel gyakorlatát hosszú évek alatt a bíróságok alakították ki, majd ezeket az eljárásokat a 2010-es évek elején többször próbálták meg kodifikálni, inkább kevesebb, mint több sikerrel.

Tanulmányom aktualitását tehát elsősorban a civil szervezetek müködésére és belső jogviszonyaira irányadó szabályozás átalakulása adja, másodsorban pedig az az igény, mely tudományos módszerrel próbálja megérteni a kérelmezők, jogi képviselők, valamint az igazságügyi dolgozók által az ügyszakban érzékelt jogbizonytalanság hátterét és eredetét.

A civil szervezetek nyilvántartási jogát részben alaptörvényi aspektusból, részben pedig a bíróságok gyakorlatának szemszögéből vizsgálom, azonban választott témám megköveteli, hogy egyes részeknél a szabályozás fejlődésének szakaszait és indokait is megvilágítsam. A szükséges legkisebb mértékben, de áttekintem a civil szervezetek társadalomban betöltött szerepét és a szabályozási környezet rendszerváltáskori, illetve a 2010-es években bekövetkezett változatait. Ezzel szemben dolgozatomban a civil szervezetek müködéséhez, gazdálkodásához, törvényességi ellenőrzéséhez és megszűnésükhöz kapcsolódó kérdésköröket csak a témám kifejtéséhez szükséges mértékben ismertetem.

A tanulmány kísérletet tesz azoknak az okoknak a feltárására, amelyek nehézzé és körülményessé tették a cégnek nem minősülő szervezetek nyilvántartásba vételét, és javaslatokat fogalmaz meg a jogszabályi környezet pontosítására, valamint

* Dr. Pálfay Szilárd bíró, Győri Közigazgatási és Munkaügyi Bíróság, Győr, szilard.palfay.dr@gmail.com. 
az egyenletesebb munkaterhet és a kiszámíthatóbb jogalkalmazást eredményező módszerek bevezetésére.

A tanulmány alapvetően ügyviteli oldalról vet fel s válaszol meg kérdéseket. Forrásai saját tapasztalatok, személyes beszélgetések, a tanulmányban alább külön is említett tanácskozások, valamint közzé nem tett bírósági határozatok (pl. a nyilvántartásba vétel iránti és a változásbejegyzés iránti kérelmekre adott hiánypótló végzések). ${ }^{1}$

\section{Előzmények}

Az egyesület, mint közös tartós cél megvalósítása érdekében létrehozott jogi személy Európa első nagy polgári jogi kódexében, a Code Civilben, még nem kapott helyet: az első komplex szabályozásra Franciaországban még több mint száz évet kellett várni. A Bürgerliches Gesetzbuchban, a német magánjogi kodifikáció egyik alapkövében a 18. és a 19. század fordulóján már megjelenik. A szabályozás határai ekkor még elmosódottak, a német jog megkülönböztet gazdasági egyesületet és bejegyzésre nem kötelezett, így jogi személynek sem minősülő egyesületet. Az egyesületek viharos elterjedésére csak a 20. század végén kerül sor. ${ }^{2}$

Az állami és a gazdasági mellett harmadikként kialakul a nonprofit civil társadalom világa, melynek az intézménytípusú jogi személy alapítvány mellett alapvető formája a széles társadalmi tevékenységi kört átfogó személyiségjellegű egyesület. Ezek részben különböző ideális célkitűzéseket szolgálnak (egészségvédelem, sportszervezés, múvészetek), részben politikai vagy szakmai érdekképviseleti jellegüek (pártok, szakszervezetek).

Fejlett egyesületi jogról az 1945 előtti Magyarországon sem beszélhetünk, az állam ebben az időszakban gyanakvóan tekintett a polgári önszerveződés alapján alakuló szervezetekre. A 19. századbeli szervezetekről csak szórványos adatok álltak a statisztikusok rendelkezésére, noha az egyleti életröl történő információgyüjtésnek már voltak hagyományai Magyarországon. Az első felmérés terve már az 1848-as forradalom idején felmerült. A terv 1862-ben az első egyesületi kimutatás elkészültével változott valósággá. Az első teljes körü felvételt pedig 1878-ban hajtották végre, melyet csak több mint ötven év múltával (1932-ben) ismételtek meg. ${ }^{3}$ Az Alkotmány ${ }^{4}$

\footnotetext{
Ugyancsak bírósági titkári tapasztalatai, illetve empirikus kutatásai alapján vetett fel kérdéseket az általam vizsgált időszakot megelőzően ANDRÉ Tibor: Az egyesületek bejegyzésével kapcsolatos joggyakorlat Veszprém megyében. Kézirat, Veszprém, 2011, http://www.civilhazveszprem.hu/files/civilszerv_bejegyz.pdf (2018. 04. 02.). A korábbi évek joggyakorlatát vizsgálta (egyesületi, illetve ügyvédi szemszögböl) egy „,kísérlet” alapján, a joggyakorlat egységét hiányolva FüLöP Sándor: Egyesületek bírósági nyilvántartásba vételi gyakorlata. EMLA Egyesület, Budapest, 2005. A civil szervezetek fogalma, társadalmi és jogi környezete (ideértve a nyilvántartásba vételt is) tekintetében mértékadó elemzést nyújtott azt megelőzően Bíó Endre: Nonprofit Szektor Analízis. Civil szervezetek jogi környezete Magyarországon. EMLA Egyesület, Budapest, 2002.

2 SÁrközy Tamás: Szervezetek státusjoga az új Ptk.-ban. HVG-Orac, Budapest, 2013, 173.

3 Balogh Bence-MészÁRos Geyza-Sebestény István: Módszer és gyakorlat: A nonprofit statisztika 10 éve $1992-$ 2002. Nonprofit, Budapest, 2003, www.nonprofitkutatas.hu/letoltendo/560_modszer.doc (2018. 05. 10.).

4 1949. évi XX. törvény 56 . §.
} 
1949 után ugyan biztosította az egyesülési jogot, de a törvényi szintű szabályozást megvalósító 1955. évi 18. tvr. kifejezetten korlátozó jellegű normának volt mondható.

A Polgári Törvénykönyvröl szóló 1959. évi IV. törvény a civil szektor szabályozási középpontjába nem az egyesület, hanem az úgynevezett „társadalmi szervezet” került, mely fogalom elsősorban az állampárt informális támogatására létrehozott félállami szervezeteket takarta. Az egyesületi jogi szabályozás a következő évtizedekben tovább fejlödött, az 1970. évi 35. tvr. már viszonylag szabaddá tette az egyesület létrehozásának feltételeit. Ettől az időponttól kezdődik az a megközelítés, hogy az egyesület jogi személyiségét a bírósági nyilvántartással szerzi meg. A jogszabály alapján helyi és országos egyesületek alakultak, belső szervezeti egységeiket pedig önálló jogi személyekké nyilváníthatták.

Az egyesületi szabályozásban a rendszerváltás alapvető változásokat hozott. ${ }^{5}$ Ettől az időponttól kezdődően az egyesületi jog szabályozását az egyesülési jogról szóló 1989. évi II. törvény látta el, új szempontokat hozva a társadalmi szervezetek szabályozási megközelítésébe. A jogszabály fő célja a többpártrendszer megalapozása volt, így ezért az egyesülési joggal alapvetően közjogi szempontból foglalkozott. A társadalmi szervezet kifejezés új, a szocialista tartalomtól eltérő értéket kapott, a pártot, érdekképviseleti szervet, szakszervezetet ettől kezdődően az egyesülési jog alapján lehetett létrehozni.

Az 1989. évi II. törvény a rendszerváltás során meghozott politikai alkuk során létrehozott kétharmados törvény volt, ez azonban a jogszabály fejlesztésének korlátját is jelentette a késöbbiekben, hiszen a módosítások elfogadására törvényhozói konszenzus hiányában nem volt lehetőség. A hézagos szabályozást a korábbi Legfelsőbb Bíróság jogfejlesztő tevékenysége, a Közigazgatási Kollégium állásfoglalásai és bizonyos különös egyesületekre vonatkozó speciális jogszabályok egészítették $\mathrm{ki}$, de nagy hatással volt a joggyakorlatra az ügyész részére biztosított fellebbezési jog és az ítélőtáblák jogfejlesztő tevékenysége is.

Az átfogó kodifikációs változtatást 2010 előtt két jelentősebb módosítás előzte meg: 1993-ban a Ptk.-ba került a köztestület, 1997-ben pedig megszületett a nonprofit törvény, vagyis a közhasznú szervezetekröl szóló 1997. évi CXLIV. törvény, amely egyes, közérdekü tevékenységet is ellátó társadalmi szervezetek részére különböző gazdasági kedvezményeket biztosított.

Miután a 2010-es választásokat követően a politikai konszenzuskényszer megszűnt, megszületett az új civil törvény, vagyis az egyesületi jogról, a közhasznú jogállásról, valamint a civil szervezetek működéséről és támogatásáról szóló 2011. évi CLXXV. törvény (a továbbiakban: Ectv., illetve Civil törvény). ${ }^{6}$

A gyülekezési és az egyesülési jogot, mint a véleményszabadság gyakorlása két megjelenési formájának szabályozását az Alaptörvény VIII. cikkelyében találjuk. Az (1) bekezdés értelmében mindenkinek joga van a békés gyülekezéshez, a (2) bekezdés szerint pedig mindenkinek joga van szervezeteket létrehozni, és joga van

5 SÁRKÖZY: i. m., 175.

6 Ennek föbb változtatásait áttekinti TóтH Emese Boglárka-RózsAvöıGYı Bálint: Az egyesületek alapítására és működésére vonatkozó szabályok legfontosabb változásai. Debreceni Jogi Mühely, 2012/2, http:// www.debrecenijogimuhely.hu/archivum/2_2012/az_egyesuletek_alapitasara_es_mukodesere_vonatkozo_ szabalyok_legfontosabb_valtozasai/ (2018. 04. 02.). 
szervezetekhez csatlakozni. A cégnek nem minősülő szervezetek közül az Alaptörvény a pártot és a szakszervezetet nevesíti. Az előbbit a nép akaratának kialakításában és kinyilvánításában közremüködő, közvetlen közhatalmat nem gyakorló szervezetként azonosítja, melynek szabályozása sarkalatos törvényben történik. Az utóbbit érdekképviseleti szervezetként jelöli, mely az egyesülési jog alapján szabadon alakulhat és tevékenykedhet.

A civil és cégnek nem minősülő szervezetekre vonatkozó szabályozás hátterét elsősorban a Polgári Törvénykönyvröl szóló 2013. évi V. törvény (a továbbiakban: Ptk.) jogi személyekre vonatkozó általános, továbbá egyesületekre és alapítványokra vonatkozó speciális szabályai adják. A megjelölt szervezetek müködésére, közhasznú jogállásának megszerzésére, gazdálkodására, megszűnésére és nyilvántartásból való törlésére vonatkozó anyagi jogi részletszabályokat az egyesülési jogról, a közhasznú jogállásról, valamint Civil törvényben találjuk.

$A z$ egyesülési jog alapján tehát magánszemélyek és jogi személyek, valamint jogi személyiséggel nem rendelkező szervezetek civil szervezeteket hozhatnak létre és müködtethetnek, továbbá olyan, civil szervezetnek nem minösülö közösséget is létre lehet hozni, amely nem müködik rendszeresen, nincs nyilvántartott tagsága.

A korábbi egyesülési jogról szóló törvény hiányos bírósági eljárási szabályait egészíti ki a Civil törvény. A civil szervezetek új Ptk. hatálya alá helyezkedésére vonatkozó kötelezettségére nézve a Ptk. hatálybalépésével összefüggő átmeneti és felhatalmazó rendelkezésekröl szóló 2013. évi CLXXVII. törvény (a továbbiakban: Ptké.) tartalmaz rendelkezéseket, a civil szervezetek bírósági eljárásokban alkalmazandó ürlapjairól a 11/2012. (II.29.) KIM rendelet szól.

Külön jogszabályok rendelkeznek az egyesületre vonatkozó előírások alapján létrejött speciális civil szervezetekröl, a pártokról, a polgárőrségekről, a vadásztársaságokról, a tűzoltó és sportegyesületekről, a hegyközségekről és a Munkavállalói Résztulajdonosi Programról is.

A Civil törvény tehát az új Alaptörvényre támaszkodik, egyszerre helyezi hatályon kívül a közhasznú szervezetekről szóló és az egyesülési jogról szóló törvényt. A témakört érintő jogalkotás a Ptk., valamint a civil szervezetek bírósági nyilvántartásáról és az ezzel összefüggő eljárási szabályokról szóló 2011. évi CLXXXI. törvény (a továbbiakban: Cnytv.) hatálybalépésével vált teljessé.

\section{Nyilvántartásba vételi problémák az új Ptk. hatálybalépését követő időszakban}

A 2014. március 15-én hatályba lépett Ptk. szabályozási elveit korábban a diszpozitív szervezeti felépítés kialakításának lehetősége jellemezte. A Ptk. Harmadik Könyve változtat ezen, és többszintü szabályozást vezet be. A civil szervezetekre is alkalmazandó jogi személyek általános szabályai körében fő szabályként a diszpozitivitást rögzítette a tagok egymás közötti és a jogi személyhez füződő viszonya, valamint a jogi személy szervezetének és müködésének szabályozása során, az eltérés korlátait a 3:4. § (3) bekezdésének a)-b) pontja határozza meg.

Az eltérést a törvény szövege csak annyiban nem engedi, amennyiben azt a törvény kifejezetten tiltja, vagy ha az eltérés a jogi személy hitelezőinek, munkavállalói- 
nak, vagy a tagok kisebbségének jogait nyilvánvalóan sérti, vagy a jogi személyek törvényes müködése feletti felügyelet érvényesülését akadályozza.

Ez két formában okozott problémát. Az egyik, hogy a jogszabály felületes szövegezése általában még teljesen alapvető, garanciális előírások esetében sem tiltotta meg a jogszabályszövegtől való eltérést. A másik, hogy a szervezet hitelezőinek, munkavállalóinak vagy a tagok kisebbsége jogainak figyelembevételére vonatkozó előírás teljesen körvonalazatlan, azzal a tételes létesítő okirati előírások vizsgálata során a Ptk. hatálybalépését követő években valójában a bírósági gyakorlat sem tudott mit kezdeni.

A megengedő jogalkotói akarat tehát olyan szabályozási autonómiát teremtett meg, amely anélkül tette semmissé az 1989. évi II. törvényen alapuló, évtizedek munkájával kialakult gyakorlatot, hogy bármi kézzelfoghatót adott volna helyette.

A jogi személyek terjedelmes általános részi szabályozásának elvileg akkor van értelme, amennyiben az egyes speciális rendelkezések azonosítható és egymástól elkülöníthető szervezeteket hoznak létre. A Ptk.-ban foglalt előírásoktól való korlátlan eltérés lehetősége nemcsak az egyes szervezeti formák közötti különbségek elmosódásához vezet, de követhetetlenné is teszi a nyilvántartásba vételhez, vagy a bejegyzett nyilvántartási adatokban bekövetkezett változásoknak változásbejegyzési eljárásban való átvezetéshez szolgáló bírósági gyakorlatot is.

A szervezetekre vonatkozó szabályok általában fundamentális normák, ettől válik tehát a szervezet azzá, ami. Az eltérés tiltását előíró szabályok teljesen ötletszerüek, több esetben nyilvánvaló hiányukat az ügyészség törvényességi ellenörzési gyakorlata és az ítélőtáblák hatályon kívül helyezésröl és új eljárásra történő utalásról szóló végzései pótolják.

Az eltérés nagy fokú megengedése és a tiltó elöírásoknak a teljes szabályozáshoz képest mért kis száma (alapítványoknál nyolc, egyesületek esetében tizenöt semmisségi következmény) miatt a nyilvántartást végző bíróságnak elvileg a létesítő okirat valamennyi tételes rendelkezésénél vizsgálnia kell, hogy az adott előírás nem sérti a munkavállalók, a hitelezők vagy a tagok kisebbségének érdekeit. Az elmúlt időszak bírósági gyakorlatából nyilvánvalóvá vált, hogy a jogszabály által lefektetett elöírásokat fő szabálynak tekintő megoldástól való elrugaszkodás felesleges, és valószínüleg évekig korrigálhatatlan jogbizonytalanságot hozott létre.

A nemzetközi magánjog - és ezzel összhangban a magyar szerződéstan - a jogszabályokat négy kategóriába sorolja: közrendi, imperatív, kógens és diszpozitív. Az elkülönítés alapja az, hogy a normák milyen mértékben és módon képezik korlátját a felek jogválasztási szabadságának. ${ }^{7}$

A jogalkalmazás során tehát annak eldöntése okozza a legtöbb problémát, hogy diszpozitívak-e azok a szabályok, ahol a Ptk. a törvénytöl való eltérés esetére nem mondja ki a létesítő okirat egy szakaszának semmisségét, ennek ellenére egy meghatározott jogszabályi rendelkezés mégsem diszpozitív. ${ }^{8}$

PALÁstı Gábor: Közrendi, imperatív, kógens és diszpozitív szabályok. Magyar Jog, 2006/2, 66-67.

8 E kérdést vizsgálja kifejezetten az egyesületekkel összefüggésben: Dzsula Mariann: Miért kógens a diszpozitív? Céghírnök, 2014/2, 3-4; METzINGER Péter: Diszpozitivitás és/vagy kogencia a magyar társasági jogban. Fontes luris, 2015/3-4, 42-55; KaPRINAY Gizella Zsófia: Az ezerarcú egyesület. Az egyesület hazai 
A tételesjogi rendelkezések értelmezését egy durva jogalkotói hiba is nehezítette: a Harmadik Könyvet kidolgozó munkacsoport által javasolt normaszöveg a 3:3. § (2) bekezdésben fö szabályként a kógenciát rögzítette, az egyes rendelkezéseket ennek megfelelően fogalmazták. A diszpozitivitás mint fő szabály kimondását követően az előírások átdolgozása nem történt meg a kívánt minőségben, így több helyen találkozunk a „kell”, „kötelező” kifejezésekkel diszpozitívnak tűnő szabályozásnál is, kritikus helyeken elmarad viszont a semmisség jogkövetkezményének feltüntetése. ${ }^{9}$

A létesítő okiratok vizsgálata során jelentkező problémák megelőzése érdekében a Debreceni Ítélőtáblán már 2014 februárjában tartottak tanácskozást annak érdekében, hogy egy úgynevezett „objektív teszt” alapján vizsgálják a Harmadik Könyv azon rendelkezéseit, melyek tárgyában a kógenciát a törvény nem mondja ki. A vizsgálat során azt kellett eldönteni, hogy a 3:4. § (3) bekezdésében meghatározott szabályozási körbe tartozik-e a rendelkezés, és amennyiben igen, eltérhetnek-e ettöl a felek, a 3:4. $\S(3)$ bekezdésében sorolt személyi körre figyelemmel. Meg kellett vizsgálni azt is, hogy amennyiben egy rendelkezés a megjelölt személyi kört nem érinti, az eltérés akadályozza-e a nyilvántartó bíróság számára a törvényes működés feletti felügyelet érvényesülését. ${ }^{10}$

A Ptk. 3:4. §-ában rögzített szervezetalakítási szabadság komoly próbája lett a bíróságok nyilvántartásba vételi eljárásának. Lássuk: mekkora szabadsága van valójában az alapító tagoknak a szervezeti felépítés meghatározása során?

A közgyűlés vagy küldöttgyülés szervezeti kialakításában nagy eltérések egyesületek esetében nem tapasztalhatóak, az ügyvezető szerv létrehozása során viszont találunk speciális megoldásokat. A jogszabály értelmében az egyesület ügyvezetését az elnökség vagy az ügyvezető látja el. A Ptk. előírásai alapján az elnökség három tagból áll. A Ptk. 3:4. §-ából következhetne, hogy a szervezet két tagból álló elnökség létrehozásáról is dönthetne, ezt azonban a bírósági gyakorlat nem támogatja. A csak a jogalkalmazásban megjelenő tiltás egyik magyarázata lehet, hogy a 3:65. $§(2)$ bekezdésében foglaltak szerint az egyesület tagjait egyenlő jogok illetik meg és egyenlő kötelezettségek terhelik, és bár az alapszabály különleges jogállású tagságot meghatározhat, egy elnökségi tag részére a további elnökségi tagénál több vagy erősebb szavazati jog nem biztosítható. Ebből az is következik, hogy kétfős ügyvezető szerv esetén kizárólag konszenzusos döntések születhetnének, erre viszont az egyszemélyi ügyvezetés alkalmasabb.

A bírósági gyakorlat tehát háromnál alacsonyabb létszámú elnökség létrehozását nem támogatja, magasabb létszámút viszont igen. Ez vonatkozik a felügyelöbizottságra is (az ügyvezetés ellenőrzését ellátó szerv a Ptk. 3:26. § alapján három tagból áll).

A jogi személy működése elképzelhetetlen a müködéshez biztosított vagyon nélkül. Az állítás nemcsak a gazdálkodó szervezetekre, de a nem profitorientált céllal létrehozott civil szervezetekre is igaz. A Ptk. 3:5. § e) pontja alapján az alapszabály-

szabályozása, annak dilemmái. PhD-értekezés, SZTE ÁJTK, Szeged, 2016, 126-145, http://doktori.bibl.uszeged.hu/3222/1/Kaprinay_Zsofia_ertekezes.pdf (2018. 04. 02.).

9 Dzsula: i. m., 3.

10 Dzsula: i. m., 4. 
ban kell rögzíteni a jogi személy részére teljesítendő vagyoni hozzájárulásokat, azok értékét, valamint a vagyon rendelkezésre bocsátásának módját és idejét.

A vagyoni hozzájárulás rendelkezésre bocsátásával és jogi megítélésével öszszefüggő problémák kritikus helyzeteket alakítottak ki a nyilvántartásba vételi és a változásbejegyzési eljárásokban. A gazdálkodó szervezetekre vonatkozó szabályozás felöl indulva a hozzájárulás a jogi személy működésének megkezdésekor a tagok által rendelkezésre bocsátott egyszeri vagyonátruházás. Célja a müködés megkezdéséhez szükséges pénzügyi és egyéb feltételek biztosítása. A vállalkozás folytatásának számviteli alapelve szerint azonban a kezdeti vagyoni hozzájárulást követően megfelelő üzleti tervvel létrehozott vállalkozásnak a kezdeti időszakot követően önfenntartóvá kell válnia, tehát szeparálódnia kell a létrehozó tagok vagyoni hozzájárulásaitól.

Ez az általános alapvetés civil szervezetek esetében nem alkalmazható, mivel azok létesítése nem gazdasági tevékenység végzésére történik. A gazdasági tevékenység végzésének tilalmára nincs előírás, de az a szervezet müködésében nem lehet elsődleges, és végzésének elsősorban a szervezet célját kell szolgálnia.

Egyesületek esetében tehát a müködési költségeket - vagy azok egy részét - általában visszatérően kell a szervezet rendelkezésére bocsátani, bár ennek megítélése ítélőtáblánként eltért egymástól. ${ }^{11} \mathrm{Az}$ egyik álláspont szerint a gazdálkodó szervezeteknél megismert vagyoni hozzájárulás fogalma egyesületek esetében nem volt értelmezhető. Más ítélőtáblai gyakorlat szerint viszont vagyoni hozzájárulásként kell tekinteni az egyesületek esetében alapszabályban meghatározott egyszeri tagi vagyoni hozzájárulásra és visszatérően fizetendő tagdíjra is. A vagyoni hozzájárulás egyesületek esetében többféle lehet, bár megjelenési formájában majdnem mindig pénz. Speciális esetei az egyszeri belépési dijj, tagdij, vagy horgászegyesületek esetében például a halasítási dij is. Az értelmezési problémákat a Ptk. 2017. évi módosítása végül tisztázta, kimondta ugyanis, hogy egyesületek esetében vagyoni hozzájárulás teljesítésére nincs szükség.

A korábbi szabályozás alapján problémát jelentett a tagok jogaira, kötelezettségeire, valamint a különleges jogállású tagokra vonatkozó előírások vizsgálata is. A Ptk. 3:65. § (2) bekezdése szerint az egyesület tagjait egyenlő jogok illetik meg és egyenlö kötelezettségek terhelik, kivéve, ha az alapszabály különleges jogállású tagságot határoz meg. A különleges jogállású tagokra példát a Civil törvény 4 . $\S$-ának (5) bekezdésében találunk, mely szerint a pártoló tag az egyesület tevékenységében csak vagyoni hozzájárulással vesz részt, a tiszteletbeli tagság pedig az egyesület tagjai által történő választással keletkezik. Ezek a tagok a jogszabály értelmében az egyesület szerveinek ülésén tanácskozási joggal vehetnek részt és vezető tisztségviselővé nem választhatóak.

11 A Győri İtélőtábla és a Debreceni Ítélőtábla közötti véleményeltérésre utalok, ami a bírósági levelezőrendszerben a civil ügyszakba beosztott bírák, titkárok, ügyintézők és jegyzőkönyvvezetők részvételével müködő levelezőcsoportban kibontakozott. A következő pontban említett, kúriai tanácskozásokon felül ez a csoport a napi egyeztetés fórumaként értelmezhető, és nemcsak a nagyobb lélegzetű jogi kérdések megvitatására, de a Civil Integrált Informatikai Rendszer (CIIR) müködésével összefüggő kisebb problémák értelmezésére vagy lajstromozási kérdések megvitatására is alkalmas. A kapcsolódó gyakorlatból lásd BDT2015. 3335. 
A szabályozás diszpozitív jellegéből következően a felsoroltaktól eltérő elnevezésủ és jogállású tagokat is felsorolhat a létesítő okirat. Ilyenek lehetnek a szavazati jogukban vagy a cél szerinti tevékenység végzésében korlátozott „ifjúsági tagok” (vadászegyesületek), a tagdíjfizetés szempontjából kedvezményben részesített „nyugdíjas tagok” vagy a feladatellátásban többletkötelezettségekkel rendelkező „vonuló tagok” (polgárőrszervezetek, tủzoltó egyesületek).

A különleges jogállásnak a bírósági gyakorlat szerint korlátai is vannak, nem járhat például többszörös szavazati joggal. Jogszabályellenes az egyesületi alapszabály olyan rendelkezése, mely a döntéshozó vagy az ügyvezető szerv határozathozatalakor szavazategyenlőség esetén a levezető elnök, az elnök vagy a döntésben részt vevők egy kiemelt tagja részére a másokéhoz viszonyítva többletszavazati jogot biztosít.

A szavazati jog gyakorlásával kapcsolatban a bírósági gyakorlat két problémakört érint. Az egyik a kiskorú tagok szavazati jogának gyakorlása, a másik a szavazati jog felfüggesztése a vagyoni hozzájárulás teljesítésének késedelme esetén. A Ptk. 3:72. §-a alapján a tag jogosult a közgyülésen részt venni, szavazati jogát gyakorolni. Az egyesület részére fizetendő tagdíj (vagyoni hozzájárulás) esedékességre való megfizetését próbálja biztosítani az az alapszabályi rendelkezés, mely fizetési késedelem esetére megvonja a tag szavazatgyakorlási jogát. Bár a szavazati jog korlátozásához a törvény nem füz semmisségi jogkövetkezményt, a bírósági gyakorlat szerint a tag mulasztása a szavazati jog megvonásával nem korlátozható.

Az új Ptk. alkalmazása során az egyesület bírósági nyilvántartásba vételekor az egyik leggyakoribb kérdés az volt: szükséges-e és ha igen, milyen részletességgel kell szabályozni a létesítő okiratban a tagsági jogviszony keletkezésére és megszűnésére vonatkozó körülményeket. A Ptk. 3:5. vagy a 3:71. §-a alapján a tagsági jogviszony keletkezésével és megszűnésével összefüggő előírások nem kötelező tartalmi elemei az alapszabálynak, a legtöbb szervezet gyakran mégis részletesen meghatározza azokat. A 2017. március 15-ét megelőző bírósági gyakorlat szerint, ha a létesítő okirat kiterjedt ezekre a szabályokra, akkor az előírásokat össze kellett hangolni a Ptk.-ban található előírásokkal; sem elhagyni nem lehetett belőle, sem kiegészíteni nem lehetett a törvényben nem szabályozott jogintézménnyel.

Jogszabályi szinten tisztázatlan volt az egyesület által történő felmondást és a kizárást megalapozó magatartások elkülönítése. Előbbi joghátrány a Ptk. 3:69. §-a alapján akkor alkalmazható, ha az alapszabály a tagságot feltételekhez köti, és a tag nem felel meg ezeknek a feltételeknek. Jóllehet a kizárási eljárás a jogalkotó szándéka szerint a súlyos vagy ismételten megvalósított szabályszegés esetére alkalmazható jogkövetkezmény, a bírósági gyakorlat ${ }^{12}$ során találkozni lehet ugyanolyan kötelezettségszegés esetén különböző Ptk.-ban szabályozott joghátrányok alkalmazásával.

Az eddig bemutatott kardinális kérdésekben megyénként eltérő joggyakorlat miatti jogbizonytalanság kétes értékü kitüntetéshez is vezetett: a 2014. évi teljesítmény alapján a „Civil szervezetek jogi szabályozása és gyakorlata” (a „Civil szervezetek-

12 A Győri İtélőtábla Pkf.III.25.660/2015/4. számú határozata. 
kel szembeni kormányzati beavatkozás" mellett) Civil Citromdijat kapott. ${ }^{13} \mathrm{Az}$ indokolás szerint a közhasznú jogállás megtartásával, illetve müködés tekintetében az új Ptk. hatálya alá helyezkedés véghatáridöhöz kötésével a két módosítás olyan zavart eredményezett, amelynek következtében kezelhetetlen ügytorlódás és teljes jogbizonytalanság alakult ki. A „méltatás” szerint tartalmi értelemben a civil szervezetek létesítését és működését, közhasznú minősítését meghatározó jogszabályok nemhogy egyszerüsödtek és megkönnyítették volna a létesítő okiratok elkészítését és módosítását, valamint a civilek életét, hanem jelentős mértékben még bonyolultabbá váltak. A civil szervezetek státuszjogszabályainak hibáiért és a bírósági nyilvántartási rendszer rossz müködéséért felelős szervek és vezetőik - csoportosan - Civil Citromdíjat érdemeltek.

A terület közmegítélése miatt egyértelmű volt, hogy lépéseket kell tenni a joggyakorlat egységesítése érdekében, és ha az nem elegendő, módosítani kell a friss polgári jogi kódexet is.

\section{Kísérlet a joggyakorlat egységesítésére}

Az új Ptk. hatálybalépése óta eltelt időszakban igény mutatkozott arra, hogy a megyénként eltérő gyakorlat országos szinten egységesüljön, illetve közös válaszok szülessenek a civil szervezetek nyilvántartásba vételével, vagy új Ptk. hatálya alá helyezkedésével kapcsolatban felmerült, és korábban meg nem válaszolt kérdésekre.

A gyakorlat egységesítését célzó törekvések között az Országos Bírósági Hivatal szervezésében a Kúrián 2015 eleje óta rendszeresen sor kerül a polgári ügyszakos, civil ügyekben jártas bírák tanácskozására. Az egyeztetések helyszínét a Kúria biztosítja, a résztvevők között a Legföbb Ügyészség, a Kúria, az ítélőtáblák, a Fővárosi Törvényszék és a Budapest Környéki Törvényszék munkatársai vesznek részt.

A felmerült témák a kezdetektöl átfogják az alapítványok és egyesületek szervezeti kialakításával, képviseletével és egyéb tagi, alapítói viszonyaival kapcsolatos olyan kérdéseket, melyeknél nem lehet egyértelmüen eldönteni, hogy az irányadó szabály diszpozitív vagy kógens. A tanácskozás eredményeként jegyzőkönyvezik a többségi álláspontot, és azt összegyűjtve közzéteszik egy belső, bírósági honlapon. ${ }^{14}$

Az ügyészség általános fellebbezési jogának megszünte után várhatóan felértékelödik a szerepe ezeknek a találkozóknak. Korábban ugyanis a megyei törvényszékek jogértelmezési szempontból inkább kényszerültek azonosulni saját ítélőtáblájuk álláspontjával, mint az említett felsőbíróságok képviselői által kialakítottal. Azzal, hogy a nyilvántartó bíróságok mentesülnek a lokális táblai gyakorlathoz való feltétlen alkalmazkodás kényszere alól, megnyílhat az út az egységes jogalkalmazás felé.

13 http://www.civilcitrom.hu/korabbi-dijazottak/civil-szervezetek-jogi-szabalyozasa-es-gyakorlata/ (2018. 04. 02.).

14 http://kpintra.justice.hu/civil-nyilvantartasi-ugyek/tanacskozas (nem nyilvános). 


\section{A Ptk., a Cnytv. és az Ectv. módosításának irányai}

Amint láttuk, a szervezetalakítás jogaként ismert egyesülési szabadságot az Alaptörvény VIII. cikk (2) bekezdésében biztosítja. Az alapjogi szabályozásból következően a törvényhozó akkor teljesíti alkotmányos kötelezettségét, ha egyértelmüen definiálja az egyes civil szervezetek létrehozásához szükséges anyagi jogi feltételeket, és eljárásjogi garanciákkal megakadályozza a nyilvántartásba vétel elhúzódását. A 2014 és 2016 közötti jogalkalmazói gyakorlat elemzése során viszont világossá vált, hogy a Ptk.-ban és a Cnytv.-ben foglalt előírások nem könnyebbé, hanem nehezebbé tették a civil szervezetek müködésének megkezdését, vagy annak az új Ptk. szabályainak való megfeleltetését.

A nyilvántartásba vételre és a bejegyzett adatokban bekövetkezett változások átvezetésére irányuló kérelmek ügyében a kérelmezők, jogi képviselők részére a jogszabály nem adott sok kapaszkodót. A Ptk. - eredeti koncepciójával ellentétben - következetlenül alkalmazta a szervezetalakításra vonatkozó diszpozitív és kógens szabályokat, a Cnytv. pedig szerkezetében és terjedelmében is alkalmatlan volt arra, hogy az alapján a jogkereső laikus polgár egyszerü megoldást találhasson problémáira.

A nyilvántartásba vételi és változásbejegyzési eljárások nagy túlzással a bíróságok és az ügyészségek játszóterévé váltak. Ellenérdekű fél hiányában a gyakorlatot csak az ügyészség fellebbezése folytán született ítélőtáblai határozatok tömkelege alakította.

Világos volt tehát, hogy a mindenütt érezhető jogbizonytalanság megszüntetéséhez nem elég az eljárási jogszabályok módosítása: elkerülhetetlen a három éve hatályba lépett polgári kódex felülvizsgálata is.

A módosítás az ügyészségi feladatkörökre is hatással volt: tarthatatlanná vált ugyanis, hogy a közérdekvédelmi feladatokat is ellátó szervezet akkor is akadályozza egy magánjogi alapon létrejött alapítvány vagy egyesület müködését, ha az általa valósnak vélt probléma közhiteles nyilvántartást nem érintett, vagy a közérdek sérelmét nem jelentette.

\subsection{Anyagi és eljárásjogi változások}

A helyzet a 2017. március 1-jével bekövetkezett módosítással alapvetően megváltozott. Ettől az időponttól kezdődően a bíróság a létesítő okirat vizsgálata során kötelező tartalmi elemként csak a jogi személy nevére, székhelyére, céljára, fő tevékenységére, a jogi személyt létesítő személyek nevére és lakóhelyére, vezető tisztségviselőire, továbbá a szervezet részére teljesítendő vagyoni hozzájárulásokra vonatkozó előírások teljesülését ellenőrizte.

A Cnytv. módosítása pontos eligazítást adott arra nézve, hogy milyen körben kell elvégezni az iratvizsgálatot: a 67 . $§(1 \mathrm{c})$ bekezdés szerint a bíróság az egyesület nyilvántartásba vétele iránti eljárásban az egyesület létesítésére, ügyvezető és képviseleti szervére vonatkozó jogszabályi rendelkezések teljesülését vizsgálja. Az eltérés nagyon jelentős: többé nem minden esetben tartozik a bíróság mérlegelési 
körébe a tag jogait és kötelezettségeit leíró alapszabályi rendelkezések vizsgálata, nem kell ellenőrzés alá vonnia az egyesület szerveinek hatáskörét, a tagokra, vezető tisztségviselőkre és a felügyelőbizottsági tagokra vonatkozó kizáró és összeférhetetlenségi szabályokat. A Ptk. 3:4. § (2) bekezdése alá tartozó létesítő okiratbeli rendelkezéseket a bíróság csak akkor vizsgálja, ha azok törvényességi felügyeleti eljárás lefolytatására adnának okot.

A bírói (bírósági titkári) mérlegelési lehetőségeket olyan módon szorítja vissza a jogszabály, hogy végre érvényesülhet a Ptk. alapelvszerü előírása a tagok egymás közötti jogviszonyának meghatározására, valamint a civil szervezet szervezeti felépítésének önálló kialakítására vonatkozó joga.

A módosítással a bírósági munka is jelentős mértékben gyorsult. A korábbi, mindenre kiterjedő iratvizsgálat egyszerüsödött, a nyilvántartási feladatokat ellátó törvényszék már nem köteles a létesítő okirat minden egyes rendelkezését megfeleltetni a helyben kialakult gyakorlatnak. Végre mindenütt alkalmazhatóvá váltak azok az iratminták is, melyeket korábban a bíróságok központi honlapján a kérelmezők segítségére tettek közzé, de mégsem fogadtak el minden megyében.

A változásbejegyzési kényszer enyhülése miatt csökkent az ügyérkezési nyomás is, így a feladatellátás zöme az új Ptk. hatálya alá való átállásról a megszünéssel, végelszámolással, kényszer-végelszámolással összefüggő eljárásokra terelődött.

\subsection{A jogorvoslati és törvényességi ellenörzési rendszer átalakitása}

A civil szervezetek működésének egyik biztosítékát korábban az jelentette, hogy felettük az ügyészség törvényességi felügyeletet gyakorolt. A törvényességi felügyeleti jog gyakorlását gyakran nem a civil szervezet tagja, hanem a nyilvántartást végző törvényszék kezdeményezte, hiszen az alapszabály- vagy jogszabályellenes müködésröl ez a szervezet rendelkezett megbízható információval.

A korábbi szabályozás alapján az ügyészség ellenőrizte, hogy a civil szervezet szabályzatai, illetve azok módosításai megfelelnek-e a létesítő okirat előírásainak, illetve hogy müködése, határozatai, a döntéshozó szerv határozatai egybevágtak-e a jogszabályokban, a létesítő okiratban vagy egyéb belső szabályzatokban előírtakkal.

A gyakorlati tapasztalatok azt mutatták, hogy a jogszabály-módosítás során a civil ügyekben megszokott ügyészi törvényességi ellenőrzést a cégbíróságon már bizonyított bírósági törvényességi felügyelet alapján meg lehet újítani. Ennek érdekében a bíróságot bizonyos esetekben (pl. beszámoló letétbe helyezésének elmaradása) bírságolási jogkörrel kellett felruházni, hiszen olyan hatásköröket vett át az ügyészségtöl, amelyhez kapcsolódóan a törvényességi felügyeletet ellátó korábbi szervnek is voltak szankciós lehetőségei. Az ügyésznek ezzel együtt minden esetben megmaradt a törvényességi felügyeleti eljárás kezdeményezéséhez való joga.

A 2017 márciusától hatályba lépett módosítások alapján a törvény egyesületek, alapítványok és sportegyesületek esetében az ügyész részére többé nem biztosít általános fellebbezési jogot, így ez utóbbi szervezet a nyilvántartásba vételről vagy a nyilvántartásba vett adatokban bekövetkezett változásokról szóló végzés jogsza- 
bálysértő rendelkezései miatt indíthat keresetet a határozat hatályon kívül helyezése vagy megváltoztatása iránt.

A jogszabály értelmében az ügyészt a perindítás joga akkor illeti meg, ha keresetét a közérdek sérelmére alapítja, és e közérdek fennállását valószínüsíti. ${ }^{15}$ A közérdek fennállásának valószínüsítését automatikussá teszi az ügyészségi törvény előírása, mely szerint, ha a törvény az ügyészt perindításra jogosítja, az eljárás közérdeküségét valószínüsíteni kell.

Az ügyész keresetindítási lehetőségét tovább egyszerűsíti a Cnytv., mely szerint fennáll a közérdek sérelme akkor is, ha az ügyész indítványában a bírósági nyilvántartás hibáját jelöli meg.

A kereseti kérelem többirányú lehet, attól függően, hogy a nyilvántartásba vételi vagy változásbejegyzés iránti kérelem, illetve az az alapján lefolytatott eljárás milyen mértékben volt jogszabálysértő. Amennyiben a jogszabálysértés csak kisebb fokú, és a nyilvántartás vezetéséhez szükséges adatok rendelkezésre állnak, a perbíróság elrendelheti a nyilvántartás módosítását vagy kiegészítését a szükséges adatokkal. Amennyiben a valósággal egyező, jogszabályszerü adattartalom nem állapítható meg, vagy a szabályos eljárás lefolytatásához jogszabálysértő állapot megszüntetésére van szükség, a bíróság felhívhatja a szervezetet a keresetben megjelölt intézkedések megtételére. Amennyiben viszont a jogszabálysértés a keresettel indult eljárásban már nem küszöbölhető ki (például mert az eljárás alapját képező végzést olyan eljárásban hozták, ahol hiánypótlás kibocsátásának nem lett volna helye), a bíróság a nyilvántartásba vételt, vagy a nyilvántartásban szereplő adatokban bekövetkezett változást elrendelő végzés hatályon kívül helyezéséről dönthet.

A nyilvántartásba vett adatok alapját képező eljárás jogszabálysértő volta miatt indított ügyészi keresetre konkrét példával is rámutatok. ${ }^{16}$ Jogszabálysértőnek találta az ügyészség az eljárást, és a nyilvántartásba vételt elrendelö végzés hatályon kívül helyezését kezdeményezte abban az esetben, amikor ellentét merült fel az alakuló közgyülés jegyzőkönyvében született határozatokban foglaltak és az alapszabályba került elöírások között. Az alapító tagok a létesítő okiratról és a vezető tisztségviselők személyéről is döntő közgyülésen az elnököt és az alelnököt együttesen gyakorolt, általános terjedelmű képviseleti joggal ruházták fel akkor, amikor a közzétett mintaokirat szerint a szervezet képviseletét csak az elnök látja el. Jogszabálysértöként jelölte meg az ügyészség azt a körülményt is, hogy a nyilvántartásba vételröl szóló végzésben a bíróság nem tüntette fel a vezető tisztségviselő megbízásának időtartamát annak ellenére, hogy a Cnytv. szerint a nyilvántartás határozott időre szóló képviselet esetében egyebek között a jogviszony megszünésének időpontját is tartalmazza. Arra tekintettel, hogy az alapeljárásra az egyszerüsített nyilvántartásba vételre vonatkozó szabályokat kellett alkalmazni, és a bíróságnak nem lett

15 BDT 2018. 3807: Az ügyész akkor indíthat pert a civil szervezet változásbejegyzési kérelmének helyt adó végzés ellen, ha keresetét a közérdek sérelmére alapítja, és e közérdek sérelmének fennállását valószínűsíti. Ugyanez a döntés írja elö, hogy a közfeladatot ellátó egyesület törvényes müködése közérdek, a jogszabályba ütköző alapszabályi rendelkezés a közérdeket sérti, az ügyészt a perindítás joga megilleti.

16 A Győri İtélőtábla Pkf.I.26.087/2014/6. számú határozata. 
volna lehetősége hiánypótlás keretében pontosítani a képviseleti joggal kapcsolatos ellentmondásokat, az ügyész a nyilvántartásba vételről szóló határozat hatályon kívül helyezését kérte.

A szükséges intézkedések megtételére hívta fel a perbíróság az ügyész keresete alapján a szervezetet akkor, amikor úgy ítélte meg: az alapítvány nyilvántartásba vételi eljárásában hiányoznak az alapítói vagyon rendelkezésre bocsátásának igazolásáról szóló formai feltételek. Az ügyész keresetében előadta, hogy álláspontja szerint közérdek füződik ahhoz, hogy Magyarországon kizárólag olyan szervezetek működjenek, amelyeknek létesítő okirata és a bejegyzés alapjául szolgáló iratok nem tartalmaznak jogszabályba ütköző rendelkezéseket. Amennyiben ugyanis egy alapítvány vagy egyesület már a megalakulása során nem tartja be a vonatkozó jogszabályokat, a közérdek védelme alapján indokolt, hogy müködését csak olyan módon folytathassa, hogy közben a jogszabálysértés kiküszöbölésére sort kerít. A Cnytv. ugyanis elöírja, hogy az alapítói vagyon rendelkezésre bocsátása során a pénzforgalmi szolgáltató, a letéteményes ügyvéd, bíróság vagy közjegyző köteles olyan nyilatkozatot tenni, mely szerint a letevő az alapítói vagyon felett a jogerős nyilvántartásba vételig nem rendelkezhet, és a letett összeget nem követelheti viszsza. A hiányos tartalmú banki nyilatkozat az alapeljárásban hiánypótlás keretében, a peres eljárás során pedig felhívás útján pótolható, így a jogszabálysértő rendelkezés csak akkor minősül hatályon kívül helyezést eredményező oknak, ha pótlására a peres eljárás során nem kerül sor.

\subsection{Peres eljárások nemperes eljárássá alakitása}

Fontos és a perbíróság ügyterhét csökkentő rendelkezés, hogy a szervezetek megszűnésével összefüggő egyes hatáskörök a peres eljárások közül a nemperes eljárások közé kerültek. A nyilvántartó bíróság az új szabályozás alapján a törvényi feltételek fennállása esetén nem a szervezet megszűnését, hanem a jogutód nélküli megszűnési ok bekövetkeztét állapítja meg. Ezt követően - attól függően, hogy a szervezetnek maradt-e vagyona vagy tartozása -, szintén a nyilvántartó bíróság dönt az eljárás egyszerüsített törlés vagy kényszer-végelszámolás formájában történő lefolytatásáról.

\subsection{A kötelező átállási határnap eltörlésének következményei}

Az új Ptk. hatálybalépését követően a Ptké. jelölte ki a civil szervezetek részére az új jogszabály hatálya alá helyezkedésének véghatáridejét. Ezek szerint az egyesületek, alapítványok és más civil szervezetek 2016. március 15. napjáig, vagyis a Ptk. hatálybalépését követő második év végéig akkor is kötelesek voltak létesítő okiratuk módosításával változásbejegyzési eljárás során intézkedni a megváltozott elöírásoknak való megfelelésről, amennyiben az alapszabály módosítására egyébként nem volt okuk. 
Amint az kiderült, a határidő lejártáig csak a civil szervezetek mintegy 25\%-a nyújtotta be a létesítő okiratát is érintő változásbejegyzési kérelmét, de a mennyiség és a jogszabály által előirt körültekintő iratvizsgálat így is elég volt ahhoz, hogy gyakran többhavi elmaradást idézzen elő a nonprofit nyilvántartások vezetésével foglalkozó ügyszakokban.

2016. március 15. közeledtével sokáig nem volt világos, hogy mi az oka a szervezetek részéről jelentkező passzivitásnak. Számítások készültek, melyek a nyilvántartási aktivitás alapján próbálták megbecsülni a nyilvántartásba vett, de ténylegesen nem müködő egyesületek és alapítványok arányát a teljes állományhoz képest. Az akkori prognózis mintegy 15-20\%-ra tette azt a szervezeti hányadot, amelytől a véghatáridőig a szétszéledt tagság vagy az időközben feladott közös cél hiánya miatt nem volt várható az eljárás megindítása. Tervek készültek arra is, hogy milyen ütemezésben történjen az ilyen szervezetek megszünésének megállapítása és a bírósági nyilvántartásból való végleges törlése. ${ }^{17}$

A 2015-ben keletkezett ügyhátralék miatt, a nyilvántartásba vétellel kapcsolatban megállapított törvényi határidők betartásának érdekében az Országos Bírósági Hivatal elrendelte a civil és egyéb cégnek nem minősülő szervezetek nyilvántartási eljárásai időszerüségének és hiánypótlási gyakorlatának országos vizsgálatát.

A vizsgálat célja elsősorban annak eldöntése volt, hogy a megjelölt ügyszakban miképpen teljesül, vagy teljesül-e egyáltalán az időszerü ügyintézés követelménye. Az ellenőrzés a törvényszékek bevonásával két időszak - egy rövidebb, három napból és egy hosszabb, három hónapból álló intervallum - elemzésével zajlott.

A vizsgálattal érintett időszak eredményeit árnyalta, hogy a közhasznú szervezetek ilyen tartalmú jogállásának nyilvántartásba vétele érdekében 2014 közepéig nyújthattak be olyan módon kérelmet, hogy közhasznú jogállásuk folytonos marad. A kérelmek benyújtása, illetve a közhasznú jogállást elveszítő szervezetek esetében a jogállást érintő változásbejegyzési eljárások átlagosan 100 százalékkal növelték az átlagos éves ügyérkezési számot, ennek elhúzódó feldolgozása a célvizsgálat időpontjában is éreztette hatását.

Az ügyhátralék feldolgozása 2016 közepére mindenütt megtörtént. A helyzetet tovább javította, hogy a jogszabály később a 2017. március 15-re kitolt véghatáridőt is eltörölte, így azok a szervezetek, amelyek eddig az időpontig nem módosították létesítő okiratukat, továbbra is a korábbi Ptk. hatálya alatt működhetnek a megszűnés megállapításának vagy törvénytelen müködés megállapításának kockázata nélkül. A törvényszékeken megszűnt ugyan a változásbejegyzési eljárások nagy száma miatti ügyérkezési nyomás, észre kell azonban venni, hogy a könnyítés hatására az elmúlt közel négy évben végül nem sikerült a civil szektort rászorítani a hatályos jogszabályoknak megfelelő müködésre.

17 A Győri Törvényszék Civil Szervezetek Irodája számítására utalok, amely a Győr-Moson-Sopron megyében tapasztalt érkezési adatokra támaszkodik. Ilyen számítás és terv 2015. június 30-tól kezdődően negyedévente készül, csak belső használatra, a törvényszék elnöke részére. 


\section{5. Összegzés}

Amint látható volt, a rendszerváltás után negyed századdal komoly igény mutatkozott a korábbi egyesülési jog újraszabályozására, a kialakult bírósági gyakorlat írásba foglalására.

Az új Ptk. több szempontból is új megközelítést hozott a nonprofit szektor jogi környezetének kialakításában. A jogalkotó a civil szervezetek müködésére, gazdálkodására, felügyeletére, ügyvezetésére vonatkozó általános szabályokat összehangolta a gazdasági társaságokra vonatkozó elöírásokkal, és a diszpozitivitás mint szervezetalakítási fő szabály bevezetésével az alapítóra, illetve az alapító tagokra ruházta a müködési feltételek meghatározását.

A látásmódjában progresszívnak tekinthető új Ptk. következetlen maradt a jogszabálytól való eltérések semmisségét kimondó klauzulák alkalmazásában. A bírósági gyakorlat csak a hatályba lépést követően két évvel jutott abba a szakaszba, hogy a nyilvántartásba vétel iránti kérelmezők részére legalább lokálisan, azaz megyénként egységes iránymutatást tudjon adni bejegyzési és változásbejegyzési gyakorlatával.

A szabályozás további két pillérét jelentő Cnytv. és Ectv. nehezen követhető szerkezeti formában gyüjti össze a civil szervezetekre vonatkozó részletes anyagi és eljárásjogot. Pontos alkalmazásuk a nyilvántartásban müködő bírósági titkárok részére nehézkes, a kérelmezők részére pedig szinte megoldhatatlan feladat.

A korábbi egyesülési jogról szóló törvényt érintő kritikákat a kodifikáció 2010 után sem tudta elcsendesíteni. A kérelmezők, a nyilvántartást vezető törvényszékek munkatársai, a törvényességi felügyeletet ellátó ügyészségek és az ítélőtáblák ítélkező bírái egyaránt tapasztalhatták, hogy a változások bonyolultabbá tették a nyilvántartásba vétel iránt indult eljárásokat, jóllehet az állami szolgáltatásokat - ideértve egyes igazságügyi nyilvántartási szolgáltatásokat is - az ügyfélközpontú megközelítés kell, hogy vezérelje.

A munkamódszerek finomítása sem változtat viszont azon, hogy a cégnek nem minősülő szervezetek nyilvántartásba vétele során jelentkező, országosan eltérő joggyakorlat problémáját csak egy dolog oldhatja meg: a Ptk., a Cnytv. és az Ectv. átfogó módosítása.

A szervezetalakítási szabadság kiterjesztése nem szolgálta a civil társadalomért tenni akarókat. Az egyesületek, alapítványok, tevékenységek sokfélesége nem igényel ezerféle szervezeti felépítést. A jogszabályváltozás iránya ezért - a jogalkalmazó szemszögéböl nézve legalábbis - nem lehet más, mint diszpozitivitás helyett kógencia. ${ }^{18}$

18 Sárközy szerint egyesületek kapcsán a diszpozivitás eleve fel sem merülhetne, hiszen az a szerződési jog (és így a szerződéssel alapított szervezetek) sajátja. SÁrközY Tamás: Az új Ptk. jogi személy könyvének néhány problémája. Ügyvédek Lapja, 2013/5, 2-7; Kaprinay a normaszöveg elemzése alapján, a jogegység megteremtése érdekében szintén változtatást javasol annak egyértelművé tétele útján, hogy az adott rendelkezések kógensek-e vagy diszpozitívak, ugyanakkor ő úgy látja, hogy a kógenciához való visszatérést megnehezíti, hogy ahhoz a Ptk. átfogó módosítására lenne szükség. KAPRINAY: i. m., 144. 


\begin{abstract}
Provisions concerning the societies and foundations raise difficulties for judges, lawyers and judicial staff proceeding in the interest of registration of non-governmental organizations for a long time. The study examines the registration of nongovernmental organizations with a view to provisions of substantive and procedural law and attempts to demonstrate problems being the cause of legal uncertainty. Finally the author puts forward a proposal for correction of regulation concerning the non-governmental organizations and suggests introducing methods in the interest of predictable application of law.
\end{abstract}

